\title{
Analysis of the Influence of Surface Condition on the Corrosion Behavior of Alloy 2024
}

Iryna Hren, Sylvia Kusmierczak, Katarína Kurajdová, Milan Luňák

Faculty of Mechanical Engineering, J. E. Purkyne University in Usti nad Labem. Pasteurova 3334/7, 40001 Usti nad Labem. Czech Republic. E-mail: iryna.hren@ujep.cz, sylvia.kusmierczak@ujep.cz, katarina.kurajdova@ujep.cz,milan.lunak@ujep.cz

Machining technology is a widely used chip technology designed for the production of segmented parts. It is widely used in almost all branches of industry, including the automotive industry. Here, the investigated alloy 2024 is widely used. A critical factor in the current design of many of these advanced systems is accurate knowledge of degradation behavior in the work environment in the context of surface condition after surface machining. If this environment causes surface discontinuities, they will significantly affect the life of the part. Corrosion behavior is considered to be an extremely critical factor due to its effect on the service life of the structure. Due to the many complexities that have developed in relation to surface condition and corrosion, little useful technical information is available. The aim of the article was to determine the effect of the surface condition on the corrosion behavior of alloy 2024. The chemical composition of the alloy was evaluated by spectral analysis. Furthermore, the samples were evaluated by confocal microscopy and the elemental distribution in the microstructure of the 2024 alloy was analyzed with emphasis on the $\mathrm{Al}_{2} \mathrm{Cu}$ phase distribution. The individual structural phases were performed using a scanning electron microscope with an EDS analyzer. This article is part of a larger experiment that will focus on the subsequent modification of this alloy, in order to change the microstructure and skin resistance of castings.

Keywords: Microstructure, Corrosion, Intermetallic phases, EDS analysis

\section{Introduction}

In recent years, there has been an increasing interest in light metal alloys, which have found application in many industries, including the aerospace, automotive and armaments industries, as well as in electrical engineering and electronics, etc. [1,2]. Duralumin's are one such type of alloy. They achieve considerable strength after curing, eg. $\mathrm{Rm}=500-600 \mathrm{MPa}$. In the production process of these alloys, such as extrusion, rolling, machining, grinding, etc., the surface of aluminum alloy products is often subjected to strong shear deformation. As a result of such deformation, deformed layers are relatively often formed in which the microstructure of the alloy differs significantly from the microstructure of the base alloy [1-8]. Such a surface-deformed layer is usually characterized by ultrathin straight grains, which significantly affect the corrosion resistance of the alloy [3, 8-9]. In general, however, these alloys are not very resistant to corrosion.

The presence of a reinforced layer can significantly affect the corrosion behavior of metallic materials due to the presence of residual stress, high dislocation density, segregation of alloying elements at grain boundaries, etc. Zhou [10] described reinforced layers on the surface of rolled aluminum alloys. In the experiments, the material was tested during hot and cold rolling. As a result of the experiments, two types of surface-deformed layers were observed: the first - with fine grains and with grain boundaries enriched with oxide particles and the second with fine grains but with grain boundaries without oxide particles. Liu et al. [11] reported that there are no typical $\mathrm{MgZn}_{2}$ curing phases in the layer stress on the surface of the mechanically polished aluminum alloy 7075 , while segregation bands develop at grain boundaries within the layer stresses, which significantly contributes to corrosion. Lin [12] performed an experiment to determine the energy in grains and the propagation of intergranular corrosion in 2xxx type aluminum alloys. During the experiments, intergranular corrosion in aluminum alloys 2024 and 2099 was investigated. During the experiments, it was found that intergranular corrosion occurs at grain boundaries that surround grains with relatively high energy reserve, and corrosion is not limited to the area immediately adjacent to grain boundaries, but grew into grains with a relatively high energy reserve, indicating that intergranular corrosion spreads within grains with a relatively high number of defects.

The susceptibility of aluminum alloys to corrosion is also affected by deformations of the layers on the surface, which occur after rolling or grinding due to the formation of fine grains and the associated redis- 
tribution of alloying elements [13-14]. Because machining causes significant shear deformations in the alloy immediately below the tool, layer stresses can occur during the process. However, little has been published about the effect of machining on the microstructure in the area close to the part surface and its effect on the corrosion behavior.

The presented experiment is part of a more extensive research focused on the study of corrosion behavior in 2024 alloy before and after its machining. The aim of the article is to investigate the corrosion behavior of aluminum alloy 2024 in a salt environment with respect to the surface condition, which is affected by changes in the microstructure properties of the surface layer caused by machining and its effect on the occurrence and spread of corrosion product in the alloy.

\section{Materials and experiments procedure}

In the experiments, alloy 2024 was produced by melting at temperatures $(750-760)^{\circ} \mathrm{C}$. The melt was cast by gravity casting into a metal mold. The mold was preheated to $300^{\circ} \mathrm{C}$ and the castings were left to cool. The resulting castings had the shape of a cylinder with a diameter of about $19 \mathrm{~mm}$ and a length of 210 $\mathrm{mm}$ and became the basis for subsequent analysis of the microstructure. The chemical composition of the casting alloy was determined by measurement on a Q4 TASMAN optical emission spectrometer. The average values of measurements are given in Table 1 . The obtained chemical composition corresponds to the standard of materials and is marked as ČSN 412024 [8].

\section{Tab. 1 Chemical composition of alloy 2024}

\begin{tabular}{|c|c|c|c|c|c|c|c|c|c|}
\hline \multicolumn{10}{|c|}{ Chemical composition [wt. \%] } \\
\hline $\mathrm{Si}$ & $\mathrm{Fe}$ & $\mathrm{Cu}$ & $\mathrm{Mn}$ & $\mathrm{Mg}$ & $\mathrm{Cr}$ & $\mathrm{Zn}$ & $\mathrm{Pb}$ & $\mathrm{Ti}$ & $\mathrm{Al}$ \\
\hline 0.54 & 0.4 & 3.75 & 0.6 & 0.5 & 0.05 & 0.11 & - & 0.028 & reduce \\
\hline
\end{tabular}

The microstructure of the starting material is shown in Figure 1. As can be seen from the picture, the dendrites have a uniform distribution and comparable size. Also in Figure 1, a locally visible occurrence of interdendritic corrosion, which is typical for this type of $\mathrm{Al}$ alloys, can be seen.

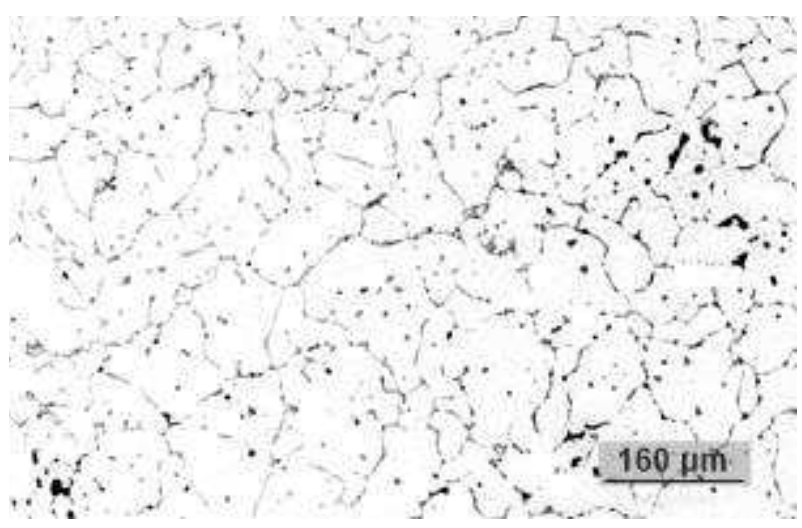

Fig. 1 Microstructure of sample 1-1 from alloy 2024, cast condition, mag. $100 x$

The microstructure of sample 2024 consists mainly of the binary eutectic $\alpha+\mathrm{CuAl}_{2}$ and a small amount of the ternary eutectic $\alpha+\mathrm{CuAl}_{2}+\mathrm{Cu}_{2} \mathrm{Mg}_{2} \mathrm{Al}_{5}$. In addition to these basic phases, there may be other phases, namely: $\mathrm{Mg}_{2} \mathrm{Si}, \mathrm{FeAl}_{3}, \mathrm{AlFeMnSi}, \mathrm{AlCuFeMn}$, etc.

For the machining experiment, 6 pieces of 2024 master alloy castings were made. The first group (containing 3 castings) was made of this alloy without further modifications (hereinafter referred to as experimental sample group 1) and the second group (another 3 samples) was made of a master alloy which has subsequently been machined (hereinafter referred to as sample group 2). The test specimens were machined on an Emco Mat - $14 \mathrm{~S}$ lathe. The lathe has a speed of 4000 min-1 with stepless regulation and a drive power of $7.5 \mathrm{~kW}[3,6,7]$. The determined cutting conditions were based mainly on the type of machine and tool used. The tool used was Pramet DCMT 070202 E UR inserts, their characteristics are summarized in $\mathrm{Ta}-$ ble 2. Based on the material being machined and the machine and tool used, the depth of cut ap $=1 \mathrm{~mm}$ and the feed per revolution $\mathrm{f}=0.12 \mathrm{~mm}$ were determined. The cutting speed vc had to be adapted to the possibilities of the used lathe Emco Mat - 14 s, especially its maximum speed $\mathrm{n}$. The cutting insert was clamped in the right outer holder SDJCR 1212 F 07 KT 016.

Tab. 2 Insert characteristics DCMT 070202 E-UR

\begin{tabular}{|c|c|c|c|c|c|c|c|c|}
\hline \multicolumn{4}{|c|}{ Dimensions $[\mathrm{mm}]$} & \multicolumn{2}{c|}{ Feed $\left[\mathrm{mm}^{\cdot} \mathrm{sw}^{-1}\right]$} & \multicolumn{2}{c|}{ Cutting depth [mm] } \\
\hline $\mathrm{l}$ & $\mathrm{d}$ & $\mathrm{d}_{1}$ & $\mathrm{~s}$ & $\mathrm{r}_{\varepsilon}$ & $\mathrm{f}_{\min }$ & $\mathrm{f}_{\max }$ & $\mathrm{a}_{\mathrm{pmin}}$ & $\mathrm{a}_{\mathrm{pmax}}$ \\
\hline 7.8 & 6.350 & 2.8 & 2.38 & 0.2 & 0.05 & 0.12 & 0.2 & 1.0 \\
\hline
\end{tabular}

\section{Roughness analysis of the machined sur- face}

After machining the samples, the roughness of the machined surfaces of the individual castings was evaluated. The surface roughness is defined in the Czech Republic by the ČSN EN ISO 4287 standard. The measurement was performed using a Hommel tester 
T 1000 measuring instrument. The data output of this instrument is in the form of a protocol. The measurements were performed five at a time and are listed in Tables 2 and 3 . The values were averaged and the mean standard deviation was determined according to Equation (1).

$$
\sigma= \pm \sqrt{\frac{\sum_{i=1}^{n}\left(x_{i}-\bar{X}\right)^{2}}{n}}
$$

Where:

$\mathrm{n}$... number of observations,

xi ... concrete realization of the quantity $X$,

$\mathrm{x}$... simple arithmetic mean of the quantity $\mathrm{X}$

Tab. 2 Surface roughness values of samples from group 1 before machining of castings, according to CSN EN ISO 4287

\begin{tabular}{|c|c|c|c|c|c|}
\hline \multirow{2}{*}{ Sample number } & \multirow{2}{*}{ Group } & \multicolumn{4}{|c|}{ Measured values } \\
\hline & & $\mathrm{Ra}[\mu \mathrm{m}]$ & $\pm \sigma \mathrm{Ra}[\mu \mathrm{m}]$ & $\mathrm{Rz}[\mu \mathrm{m}]$ & $\pm \sigma \mathrm{Rz}[\mu \mathrm{m}]$ \\
\hline $1-1$ & \multirow{6}{*}{1} & 4.070 & 0.1692 & 24.904 & 5.7607 \\
\hline $1-2$ & & 4.103 & 0.4902 & 18.224 & 2.1397 \\
\hline $1-3$ & & 4.496 & 0.3003 & 15.333 & 3.8932 \\
\hline $1-4$ & & 3.997 & 1.1932 & 15.925 & 1.0173 \\
\hline $1-5$ & & 4.770 & 0.9305 & 25.736 & 3.4505 \\
\hline $1-6$ & & 3.992 & 0.5678 & 15.181 & 2.4203 \\
\hline
\end{tabular}

Tab. 3 Surface roughness values of samples from group 2 before machining of castings, according to CSN EN ISO 4287

\begin{tabular}{|c|c|c|c|c|c|}
\hline \multirow{2}{*}{ Sample number } & \multirow{2}{*}{ Group } & \multicolumn{4}{|c|}{ Measured values } \\
\hline & & $\mathrm{Ra}[\mu \mathrm{m}]$ & $\pm \sigma \mathrm{Ra}[\mu \mathrm{m}]$ & $\mathrm{Rz}[\mu \mathrm{m}]$ & $\pm \sigma \mathrm{Rz}[\mu \mathrm{m}]$ \\
\hline $2-1$ & \multirow{6}{*}{2} & 0.996 & 1.2774 & 3.645 & 0.7533 \\
\hline $2-2$ & & 0.993 & 0.8282 & 3.356 & 0.2827 \\
\hline $2-3$ & & 1.072 & 0.6478 & 3.375 & 0.3426 \\
\hline $2-4$ & & 0.987 & 0.6485 & 2.581 & 0.9405 \\
\hline $2-5$ & & 0.952 & 0.9540 & 2.236 & 0.8399 \\
\hline $2-6$ & & 0.990 & 0.5781 & 2.580 & 0.9284 \\
\hline
\end{tabular}

From the above data it is clear that machining had a great effect on the surface roughness, and the difference between the un-machined and machined surface is its reduction from about $4 \mu \mathrm{m}$ to $0.98 \mu \mathrm{m}$. Only the roughness $\mathrm{Ra}$ is noticeable, but due to the method of production of castings (gravity casting) it can only mean an irregularity in the structure of the casting.

\section{Microscopic evaluation of corrosion attack of alloy according to ČSN 038137}

In the next part of the experiments, a salt spray test was performed according to CSN 038137. The samples were exposed to corrosion in the Liebisch S400 MTR corrosion chamber for the time specified in the ČSN ISO 8407 standard [15]. The test was graded with exposure times of 96, 168, 240, 480, 720 and 1008 hours. The individual cycles were performed in a test medium of $5 \% \mathrm{NaCl}$, concentration $50 \mathrm{~g} / \mathrm{l}$, at a temperature of $(350 \mathrm{C} \pm 20)^{\circ} \mathrm{C}$, and $\mathrm{pH}$ of the solution was 6.5 to 7.2. The exposure time and labeling of the samples are given in Table 4 .

At the end of the test, the corrosion products of the samples were removed, then the samples were cleaned and dried. Metallographic sections of each sample were prepared to evaluate corrosion attack. The samples were evaluated using an Olympus LEXT 5000 light microscope. After 96 hours of exposure in the corrosion chamber (Figure 2), uneven local areas of corrosion attack were visible on the surface, from the microscopic point of view it was pitting corrosion. After longer exposure times, the infestation increased in all directions. For clarity, in Figure 3 to 5 show examples of pitting corrosion in the samples after 168, 240, 480 h. In Figure 3, the interdendritic porosity phase at the grain boundaries and also at the grain boundaries is probably still excluded. The only exception was sample 2-5 and 2-6 (see Figures 6 and 7) after 720 and $1008 \mathrm{~h}$ of exposure. In Figure 6 shows the microstructure of uneven distribution of pitting and intergranular corrosion. Intergranular corrosion is closely related to the occurrence of interdendritic intermetallics, and penetrates up to $95 \mu \mathrm{m}$ below the alloy surface. As can be seen from Figure 6 and 7 intergranular corrosion propagates along the grain boundaries, which are formed by $\mathrm{Al}_{2} \mathrm{Cu}$.

Tab. 4 Marking of 2024 alloy samples after corrosion test

\begin{tabular}{|c|c|c|c|c|c|c|}
\hline $\begin{array}{c}\text { Group of } \\
\text { samples }\end{array}$ & after $96 \mathrm{~h}$ & after $168 \mathrm{~h}$ & after $240 \mathrm{~h}$ & after $480 \mathrm{~h}$ & after $720 \mathrm{~h}$ & after $1008 \mathrm{~h}$ \\
\hline 1 & sample 1-1 & sample 1-2 & sample 1-3 & sample 1-4 & sample 1-5 & sample 1-6 \\
\hline 2 & sample 2-1 & sample 2-2 & sample 2-3 & sample 2-4 & sample 2-5 & sample 2-6 \\
\hline
\end{tabular}




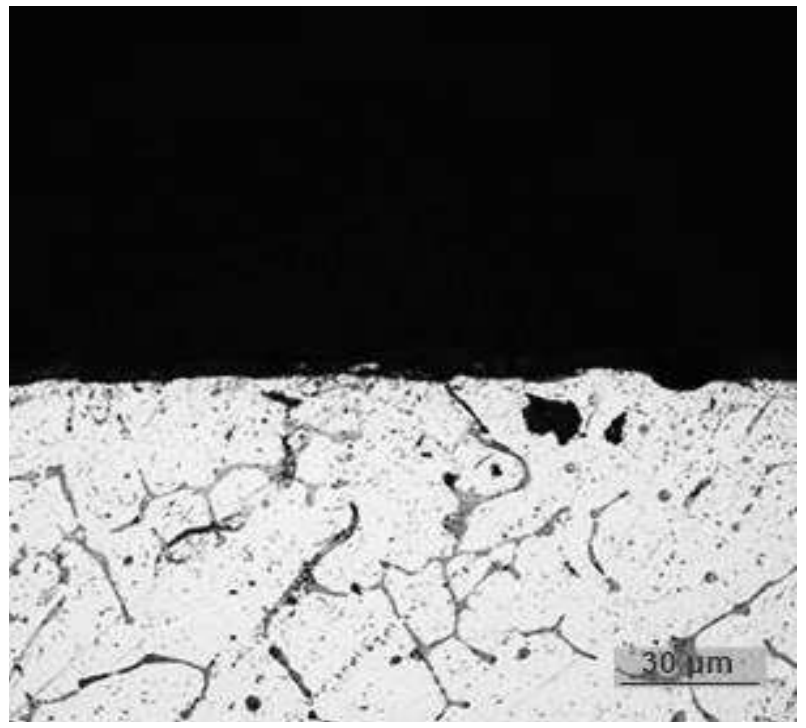

Fig. 2Microstructure of sample No. 1-196 bours of corrosion exposure, mag. $500 x$

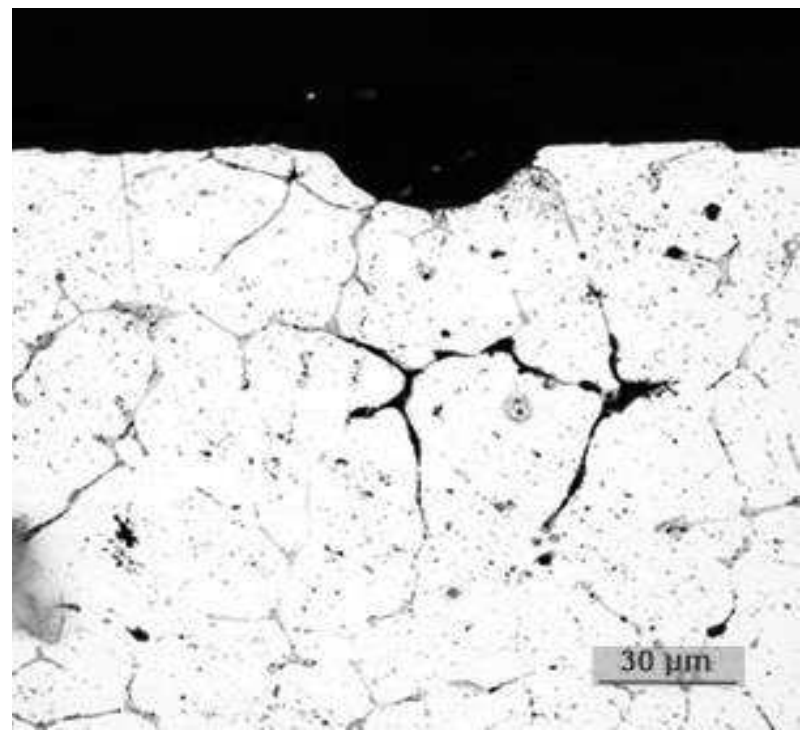

Fig. 3 Microstructure of sample No. 1-2, pitting corrosion, 168 hours exposure, mag. $500 x$

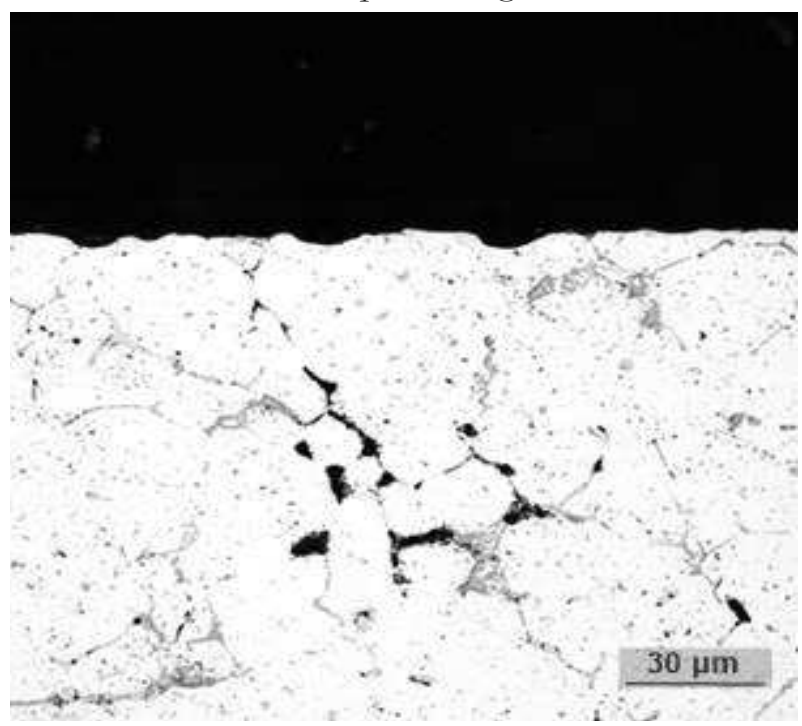

Fig. 4 Microstructure of sample No. 1-3 with uneven pitting corrosion after 240 hours, mag. $500 x$

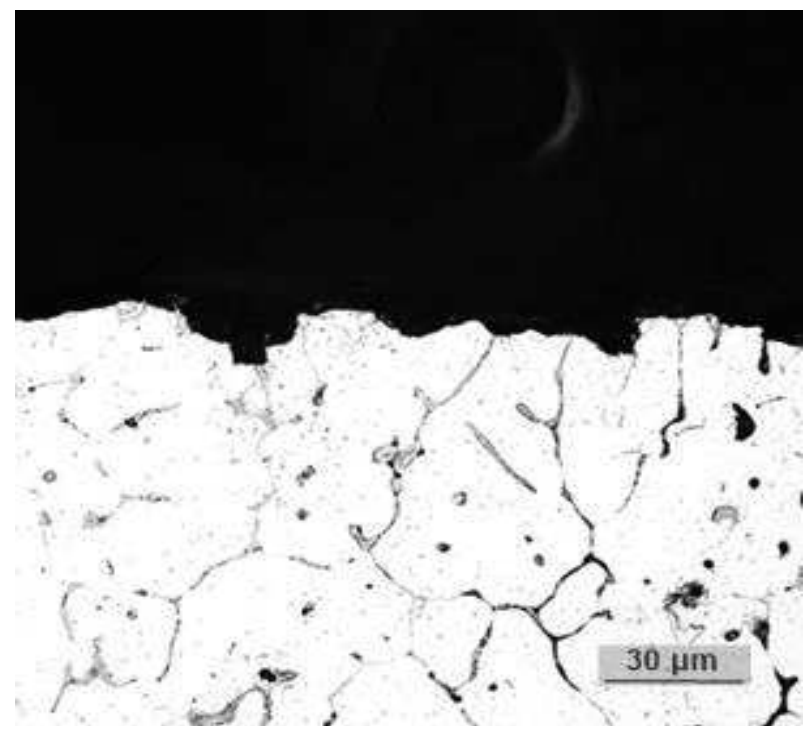

Fig. 5 Microstructure of sample No. 1-4 with pitting corrosion after 480 hours, mag. $500 x$

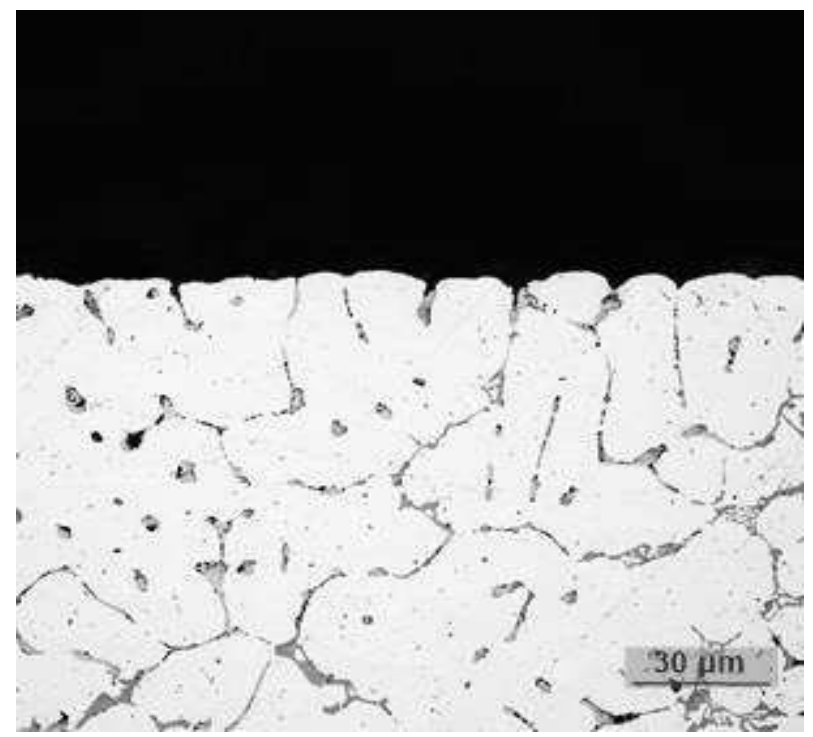

Fig. 6 Microstructure of samples No. 1-5 with pitting corrosion after 720 hours, mag. $500 x$

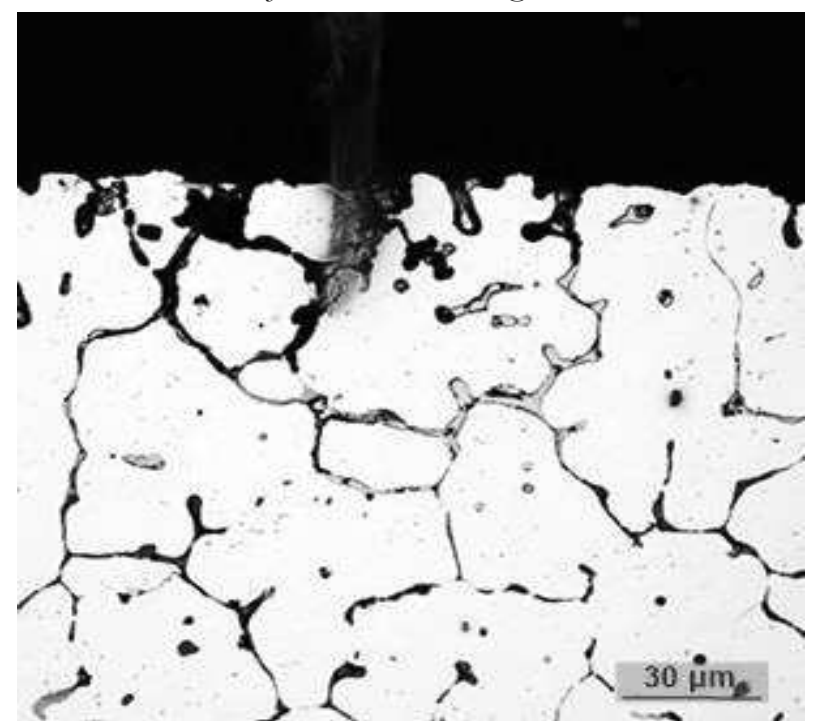

Fig. 7 Microstructure of sample No. 1-6 with intercrystalline corrosion after 1008 hours, mag. $500 x$ 
Based on these evaluations, it was found that the character of surface attack is in all samples of alloy 2024, except for sample No. 1-6 (Figure 7) after 1008 $\mathrm{h}$ of exposure in the corrosion chamber.

In the next part of the experiments, the corrosion degradation of the samples after their machining was evaluated. In Figures 8 to 10, as with unmachined samples, an uneven pitting distribution can be seen. Pitting corrosion occurs in dendritic nuclei [12], because $\mathrm{Cu}$ is depleted by microsegregation processes in these areas. Dendritic nuclei thus become more active than the rest of the dendrites, which is reflected in a change in chemical composition and subsequent change in the electrode potential and thus a change in resistance to the corrosive environment, as confirmed by research [16-18].

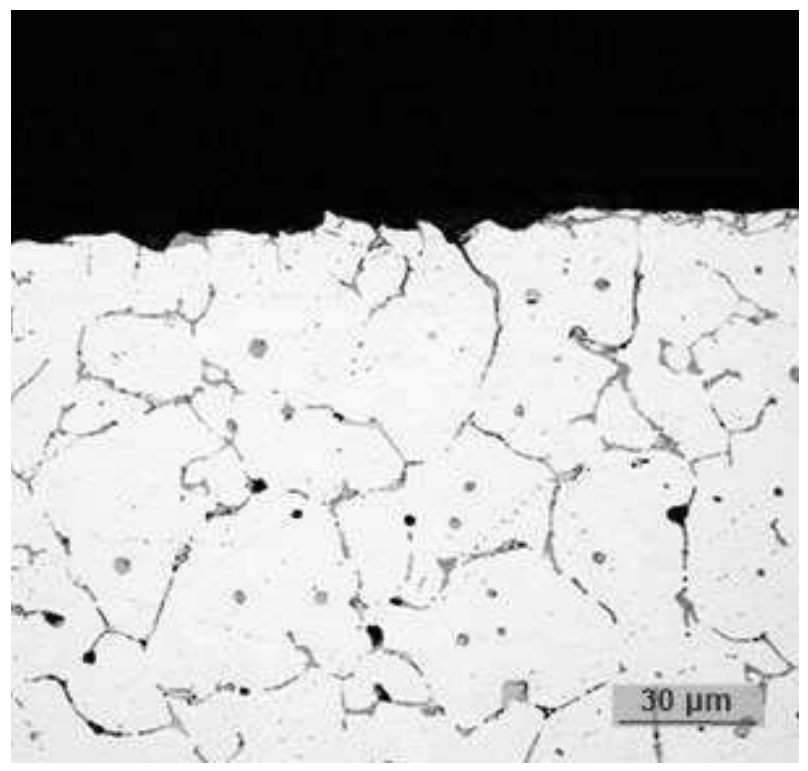

Fig. 8 Microstructure of samples 2-1 with uneven pitting corrosion after 96 hours, mag. $500 x$

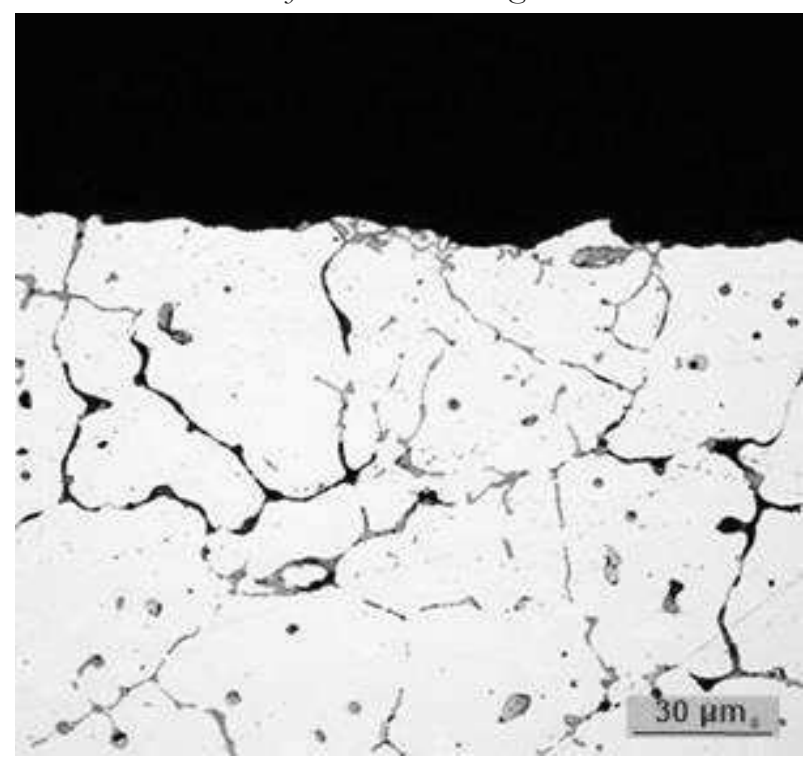

Fig. 9 Microstructure of sample 2-2 with non-uniform pitting corrosion and intermetallic phase of $\mathrm{AlCuFeMn}$ type in the form of Chinese script after 168 hours, mag. $500 x$

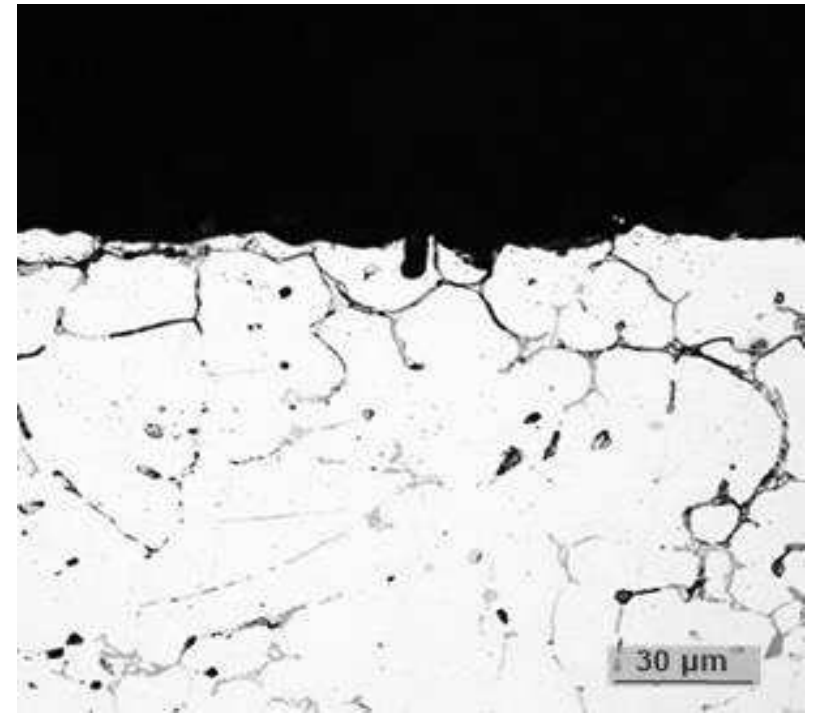

Fig. 10 Microstructure of sample 2-3 with significant pitting corrosion after 240 hours, mag. $500 x$

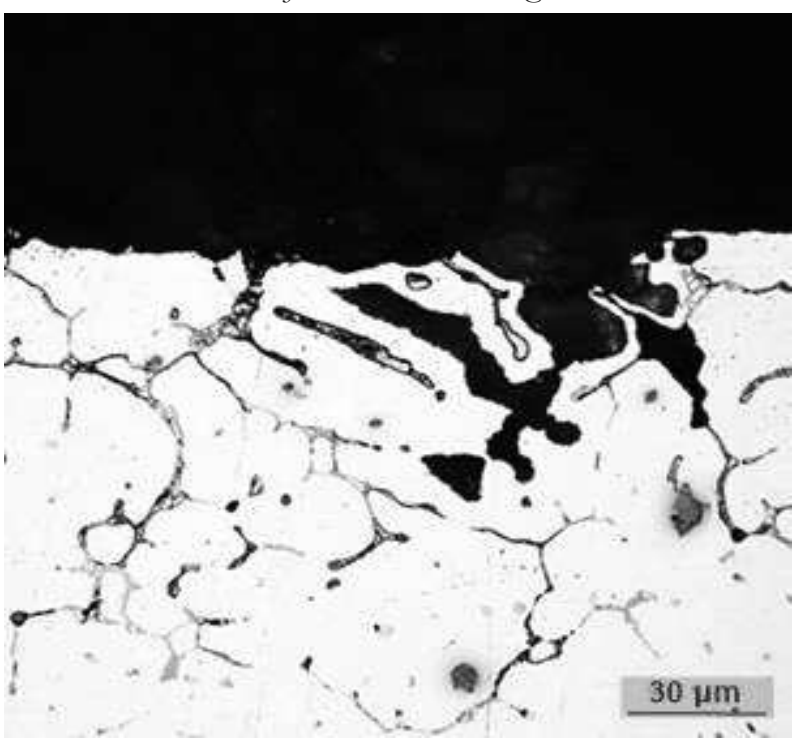

Fig. 11 Microstructure of samples 2-4 with intergranular corrosion after 480 hours, mag. $500 x$

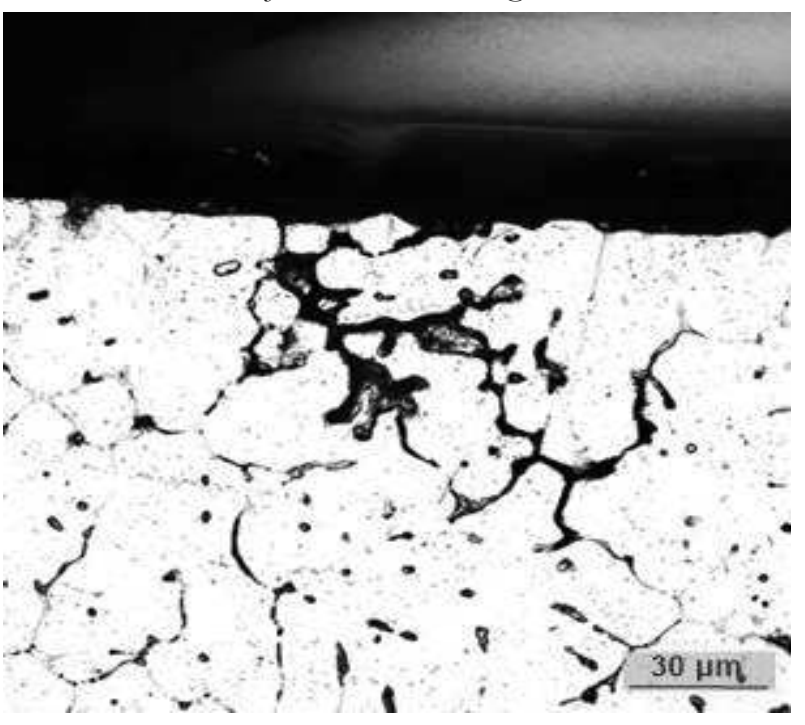

Fig. 12 Microstructure of sample 2-5 with corrosion along grain boundaries after 720 hours, mag. $500 x$ 


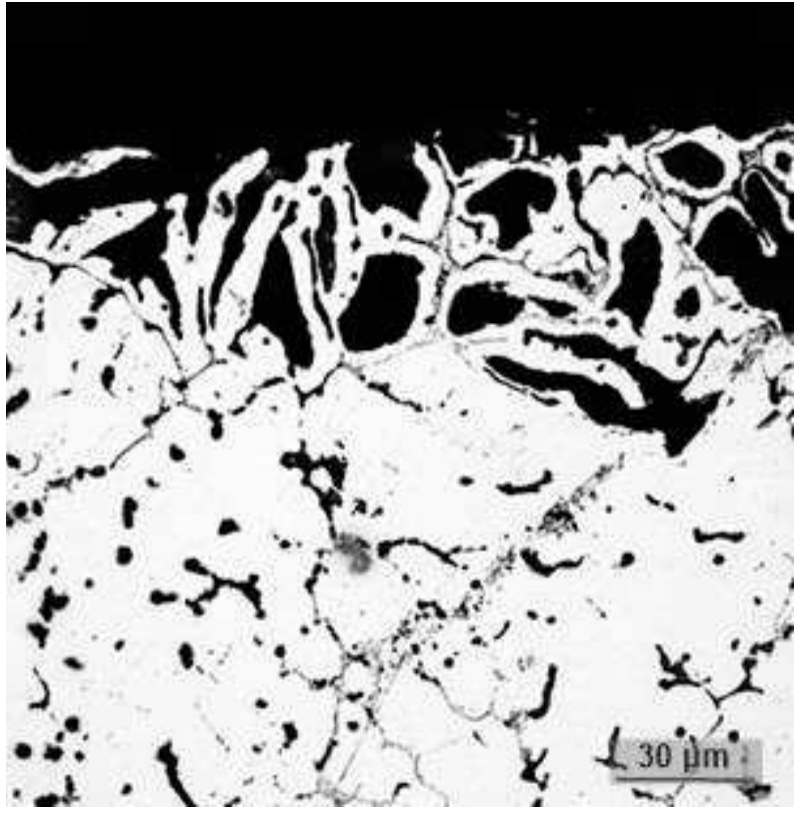

Fig. 13 Microstructure of sample 2-6 from intercrystalline corrosion after 1008 hours of corrosion exposure, mag. $500 x$
Sample No. 2-4 to 2-6 (Figures 11 to 13) showed high-intensity intercrystalline corrosion. As can be seen from Figure 11 and 12, corrosion begins to act at grain boundaries that are rich in $\mathrm{Al}_{2} \mathrm{Cu}$ and continues in areas of the $\alpha$-phase that is depleted of $\mathrm{Cu}$. The corrosion of the $\alpha$-phase can be explained by the galvanic connection between $\mathrm{Al}_{2} \mathrm{Cu}$ and the $\alpha$-phase, because $\mathrm{Al}_{2} \mathrm{Cu}$ is cathodic with respect to the $\alpha$-phase [18]. Figure 13 clearly shows that the corrosion is located in two areas. The first is the $\alpha$-phase adjacent to the interdendritic regions, consisting mainly of $\mathrm{Al}_{2} \mathrm{Cu}$, and the second are the dendritic nuclei, corroded by the mechanism described above.

\section{Electron microscopy - EDS analysis}

A Tescan VEGA3 electron microscope was used to examine the microstructure of the alloy sample using SEM. The chemical composition of selected phases precipitated in the microstructure was determined by energy dispersive spectrometry (EDS) using a Bruker EDS analyzer.

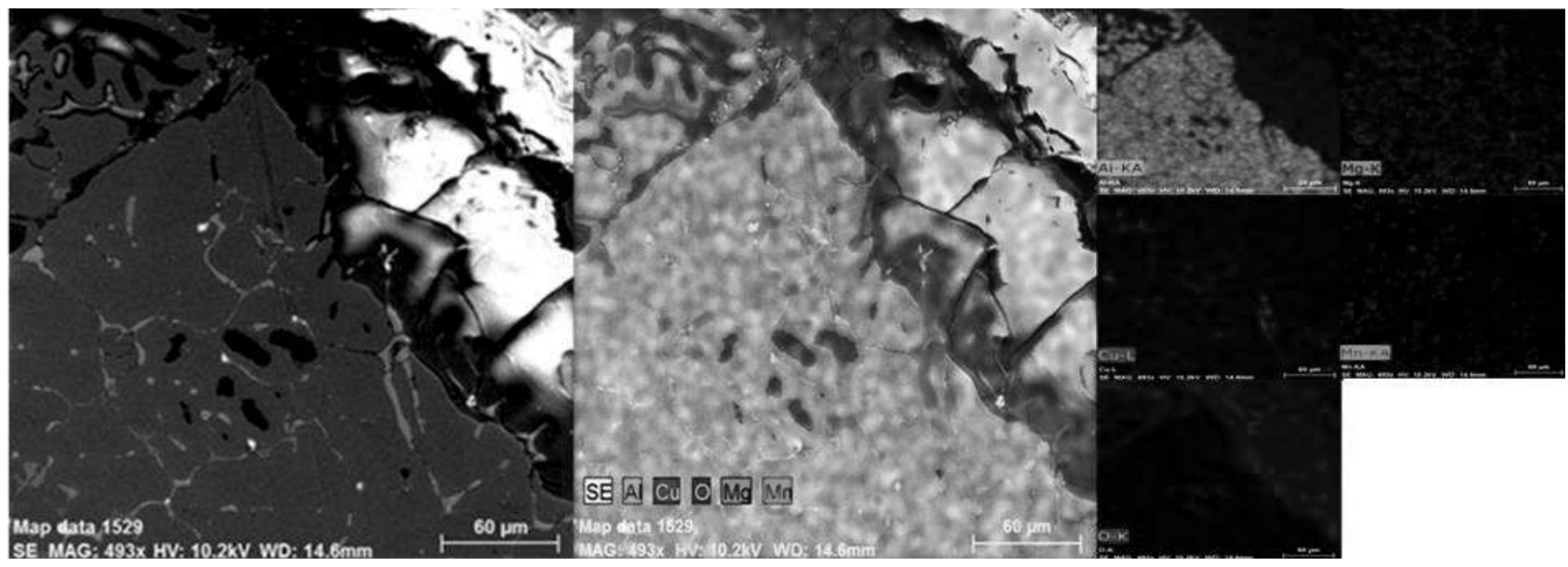

Fig. 14 Microstructure of sample No. 1-3, elemental cross-sectional maps of the sample in alloy 2024

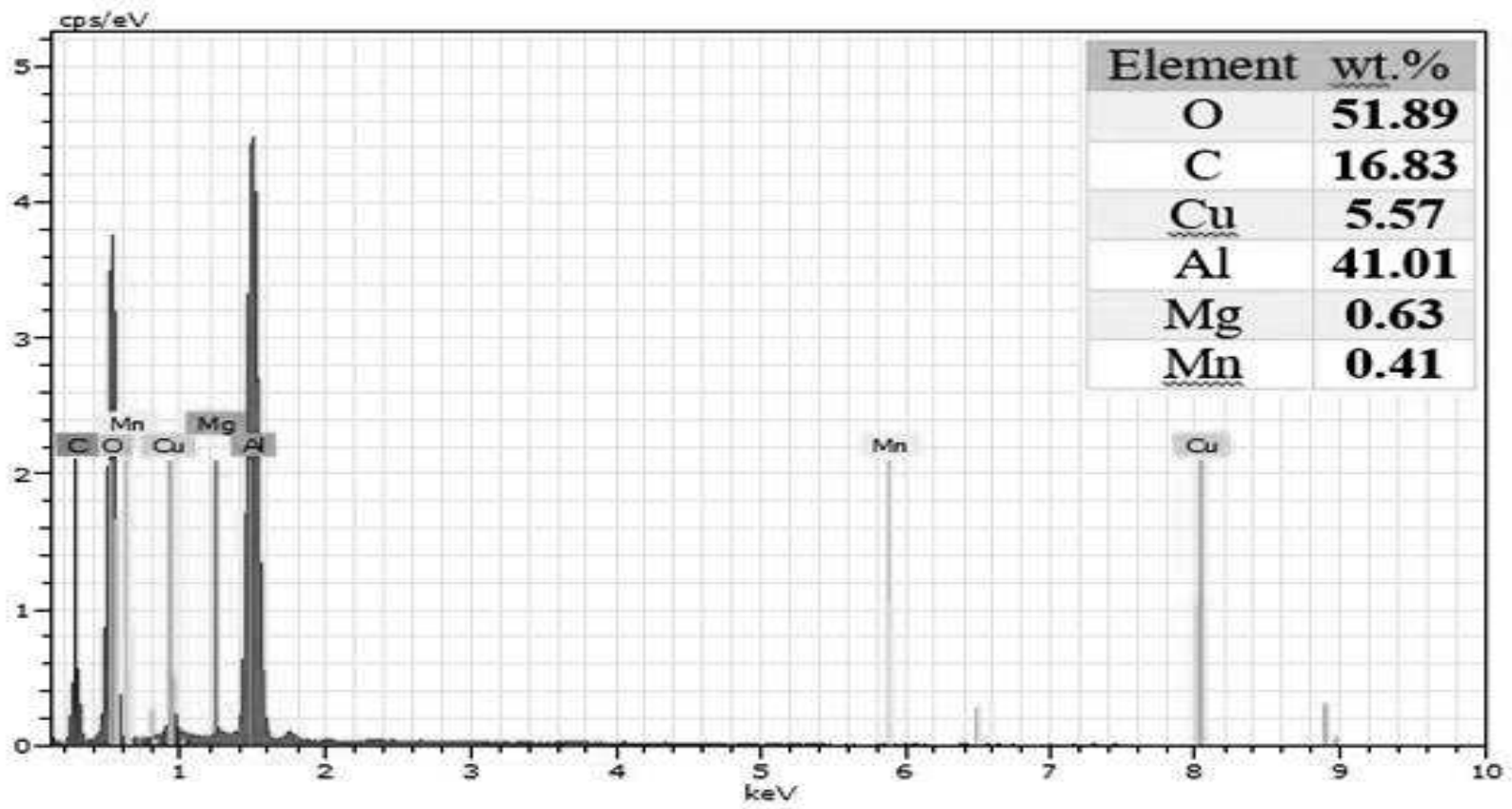

Fig. 15 Spectrum of analyzed chemical elements from samples 1-3 and quantification of the results of area EDS analysis 


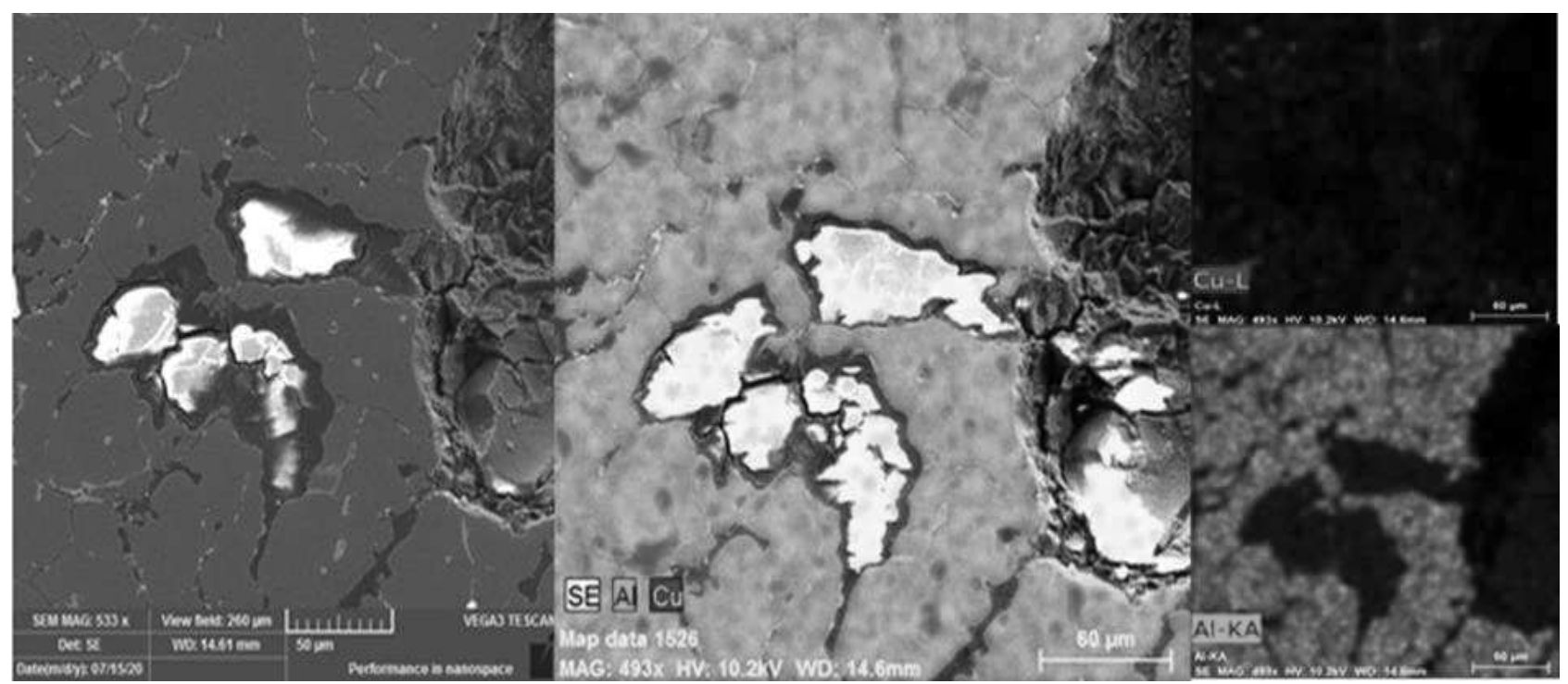

Fig. 16 Microstructure of Sample No. 2-1 and elemental maps of atoms on the surface of alloy 2024

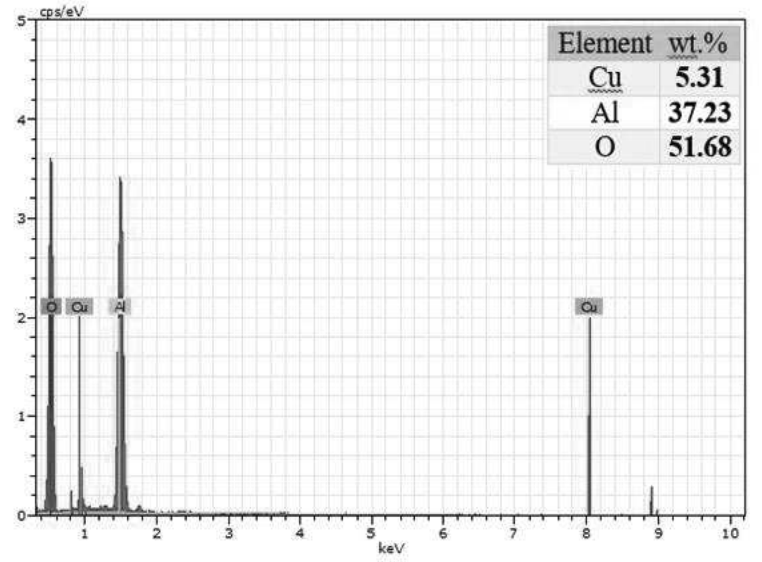

Fig. 17 Spectrum of analyzed chemical elements of samples No. 2-1 and quantification of the results of the area EDS analysis
Figure 14 and 15 show the areas of corrosion attack and the subsequent mapping of these areas. It can be seen from Figure 14 that in this area corrosion products have penetrated into the $\alpha$-matrix that surrounds them. An increased distribution of $\mathrm{O}$ was observed. This confirms the recording of the area EDS analysis and the quantification of the results of the area EDS analysis in both areas (Figure 15 and 17), where the oxygen content up to about $52 \%$ wt. was captured.

In another area of corrosion, EDS analysis of the element map of atoms on the surface of alloy 2024 was also performed (Figure 18). The presence of intergranular corrosion has also been documented in this area. In the area of corrosion propagation, a Cu-rich region can be seen, it can be assumed that these are intermetallic phases of $\mathrm{Al}_{2} \mathrm{Cu}$.

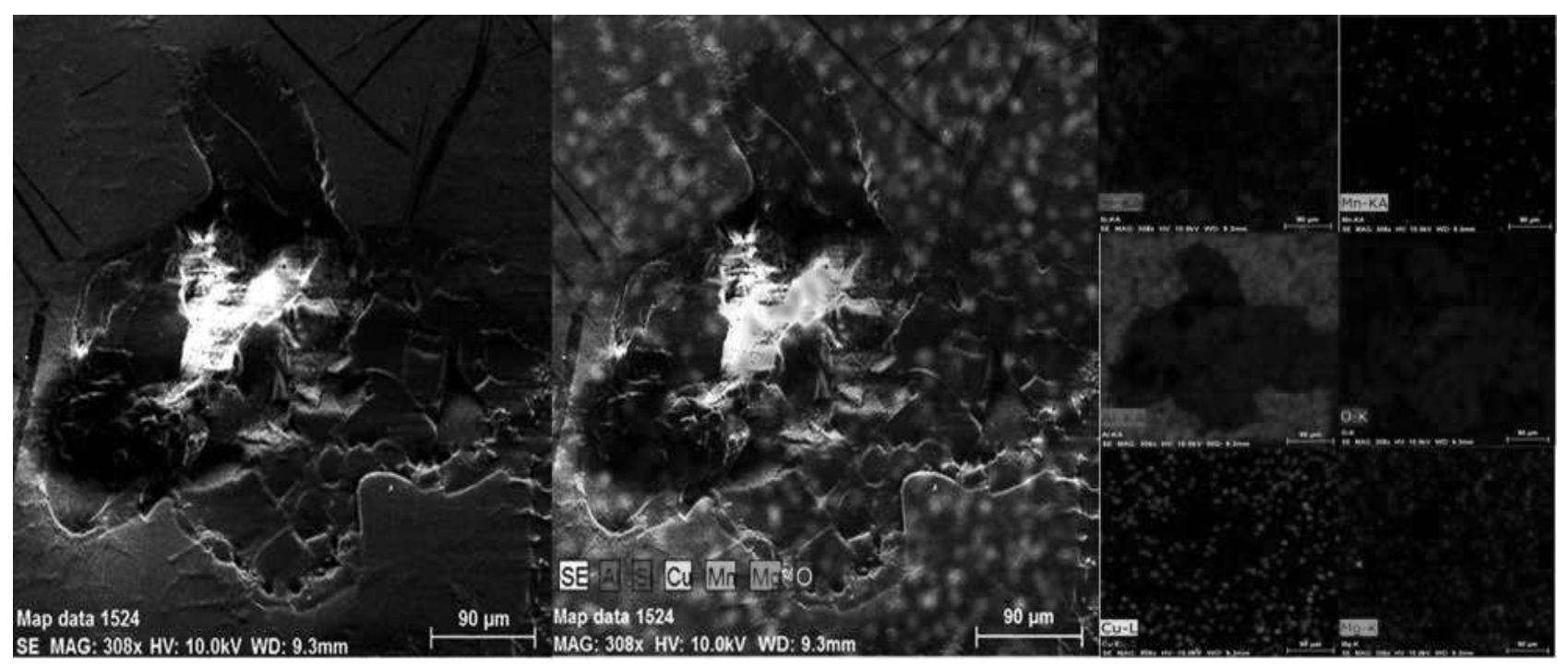

Fig. 18 Microstructure of the sample No. 2-5 and element maps of atoms on the surface of the alloy 2024 


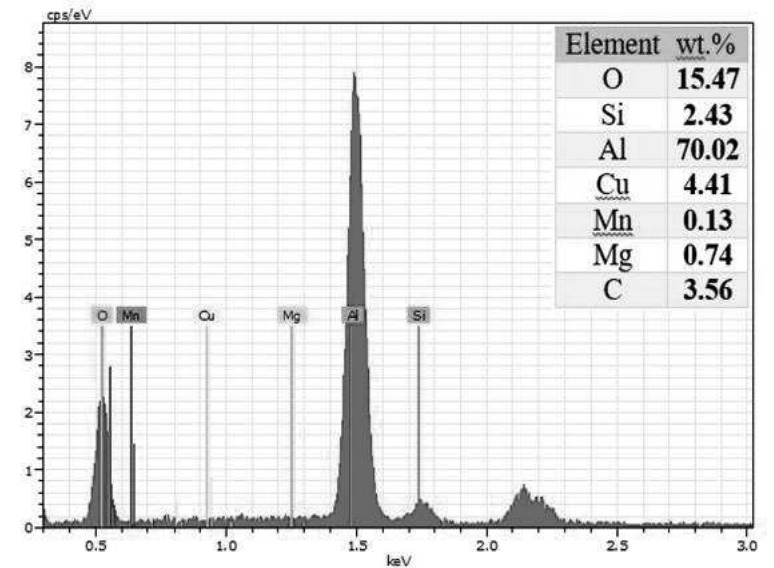

Fig. 19 Spectrum of analyzed chemical elements from samples No. 2-5 and quantification of the results of its area EDS analysis

From Figure 18 it can be seen that $\mathrm{O}$ was uniformly distributed throughout the area, which is confirmed by the recording of the area EDS analysis and the quantification of the results of the area EDS analysis in Figure 19.

\section{Conclusion}

Based on the performed experiments, two groups of samples were made from alloy 2024, which differed in surface roughness and which were subsequently subjected to a detailed examination, in which the influence of corrosion attack on the structure of the material before and after its machining was studied. Based on the performed analyzes, the following conclusions were reached:

In a sample of the first group (before machining) after 96 to 480 hours of salt spray exposure, an uneven distribution of pitting and intergranular corrosion, which occurs in dendritic cores, was found because these areas are depleted of $\mathrm{Cu}$ in microsegregation. In the sample after 720 and 1008 hours of salt spray exposure, the microstructure shows an uneven distribution of pitting and intercrystalline corrosion closely associated with interdendritic phases, with penetration up to $95 \mu \mathrm{m}$ below the alloy surface. Pitting corrosion was found in machined samples after 96 to 240 hours of salt spray exposure, as well as in samples without machining. Samples after 480 to 1008 hours of salt spray exposure show intergranular corrosion, which begins to act at grain boundaries that are rich in $\mathrm{Al}_{2} \mathrm{Cu}$ and continues in areas of $\alpha$-phase, which is depleted of $\mathrm{Cu}$, area EDS analysis confirmed areas of intergranular corrosion in $\alpha$-matrix, and an increased distribution of $\mathrm{O}$ was observed.

Based on the performed experiments, it can be clearly stated that the process of machining $2 \mathrm{xxx}$ type alloys removes the characteristic surface layer $\mathrm{Al}_{2} \mathrm{O}_{3}$, which serves as a natural protective barrier and further manifests itself in increased roughness, which affects wetting during the corrosion test, which reduces corrosion properties of the alloy. To improve the surface quality of this alloy, it is necessary to perform, for example, a coating or an alloy modification process that increases the corrosion resistance of the material. As mentioned, the presented article is an initial experiment that serves as a starting point for further research, which will focus on changing the microstructure, machinability and corrosion resistance of 2024 alloys.

\section{Acknowledgement}

The article was created within the project support with the contribution of grant support SGS 48207 15 2014-48 01 Jan Evangelista Purkyně University in Ústí nad Labem.

The article was created within the project support with the contribution of grant support SGS 48207 15 2023-48 01 Jan Evangelista Purkyně University in Ústí nad Labem.

The article was created within the project support with the contribution of grant support SGS 48207 15 2026-48 01 Jan Evangelista Purkyně University in Ústí nad Labem.

The article was created within the project support with the contribution of grant support UJEPIGA-TC-2019-48-01-2 Jan Evangelista Purkyně University in Ústí nad Labem.

\section{References}

[1] MILLER, W.S., ZHUANG, L., BOT'TEMA, J., WITTEBROOD, A.J., SMET, P.D., HASZLER, A. (2000). Recent development in aluminium alloys for the automotive industry. Compos Sci Technol, Vol. 280, No. 1, pp. 37-49. Elsevier. ISSN 0266-3538.

[2] VARGEL, CH. (2004). Corrosion of aluminium. Elsevier. ISBN 978-0-08-044495-6

[3] VOJTĚCH, D., KUČERA, V. (2017). Influence of the Heat Treatment on Corrosion Behaviour and Mechanical Properties of the AA 7075 Alloy. Manufacturing Technology, Vol. 17, No. 5, pp. 747-752. ISSN 1213-2489.

[4] KOVALČÍK T, STOULIL J, SLÁMA P, VOJTĚCH D. (2015). The Influence of Heat Treatment on Mechanical and Corrosion Properties of Wrought Aluminium Alloys 2024 and 6064. Manufacturing Technology, Vol. 15, No. 2, pp. 148-155. ISSN 1213-2489.

[5] ECKERMANN, F., SUTER T., UGGOWITZER P. J., AFSETH A., SCHMUTZ P. (2008). Investigation of the exfoliation-like attack mechanism in relation 
to Al-Mg-Si alloy microstructure. Corrosion Science, Vol. 50, p. 2085 - 2093. ISSN 0010-938X.

[6] LUO, C., ZHOU, X., THOMPSON, G. E., HUGHES, A. E. (2012) Observations of intergranular corrosion in AA2024-T351: The influence of stored energy. Corrsoion Science, Vol. 61, pp. 35 - 44. ISSN 0010-938X.

[7] SOBOTKA J, SOLFRONK P, KOLNEROVA M, KORECEK D. (2018). Influence of Technological Parameters on Ageing of Aluminium Alloy AW-2024. Manufacturing Technology, Vol. 18, No. 6, pp. 1023-1028. ISSN 1213-2489.

[8] MICHNA, Š., KUŚMIERCZAK, S., NÁPRSTKOVÁ, N. (2009). Výskyt koroze u eloxovaných hliníkových polotovarů. In: Transaction of the Universities of Kosice, pp. 268-274.ISSN 1335-2334.

[9] KUBÁSEK J, VOJTĚCH D. (2013). Mechanical and corrosion properties of $\mathrm{Mg}$ based alloys considered for medical applications as biodegradable materials. Manufacturing Technology, Vol. 13, No. 3, pp. 334-341. ISSN 1213-2489.

[10] ZHOU, C., YANG, X., LUAN, G. (2006). Effect of root flaws on the fatigue property of friction stir welds in 2024-T3 aluminum alloys. Mater Sci Eng A, Vol. 418, pp. 155-160. ISSN 0921-5093.

[11] LIU, X.F., HUANG, S.J., GU, H.C. (2002). Crack growth behaviour of high strength aluminium alloy in $3.5 \% \mathrm{NaCl}$ solution with corrosion inhibiting pigments. Int Fatigue, Vol. 24, pp. 803-809. ISSN 0142-1123.

[12] LIN, Y., JIANG, Y., XIA, Y., ZHANG, X., ZHOU, H. (2014). Deng Effects of creep-aging processing on the corrosion resistance and mechanical properties of an Al-Cu-Mg alloy. Mat Sci Eng A, Vol. 605, pp. 192-202. ISSN 09215093.

[13] MCNAUGHTAN, D., WORSFOLD, M., ROBINSON, M.J. (2003). Corrosion product force measurements in the study of exfoliation and stress corrosion cracking in high strength aluminium alloys. Corros $S_{c i}$, Vol. 45, No. 10, pp. 2377-2389. ISSN 0010-938X.

[14] EIVANI, A.R., ZHOU, J., DUSZCZYK, J. (2016). Mechanism of the formation of peripheral coarse grain structure in hot extrusion of Al-4.5Zn-1Mg. Philos Mag (Abingdon), Vol. 96, No. 12, pp. 1188-1196. ISSN 1478-6435.

[15] ČSN EN ISO 9227 (038132) Korozní zkoušky $\mathrm{v}$ umělých atmosférách - Zkoušky solnou mlhou.

[16] TILlOVA, E., CHALUPOVA, M., HURTALOVA, L., DURINIKOVA, E. (2011). Quality Control of Microstructure in Recycled Al-Si Cast Alloys. Manufacturing Technology, Vol. 11, No. 11, pp. 70-76. ISSN 12132489.

[17] HREN, I., MICHNA, S., SVOBODOVA, J., MICHNOVA, L., \& BENES, L. (2020). Analysis of the defects occurrence on the functional surfaces of individual mould segments for the tyre production from AlSi7Mg0.3Sr. Proceedings of the Institution of Mechanical Engineers, Part C: Journal of Mechanical Engineering Science, Vol. 234, No. 17, pp. 3474-3483. ISSN 0954-4062.

[18] KUSMIERCZAK, S., HREN, I. (2019). Influence of AlSi7Mg0.3 alloy modification on corrosion behaviour in the salt environment. Manufacturing Technology, Vol. 19, No. 5, pp. 802-806. ISSN 1213-2489. 